\title{
ACRL Programs at the Kansas City Conference
}

\section{PRECONFERENCE PROGRAMS}

The Preconference meeting of the College Libraries Section of ACRL was held at the University of Kansas in Lawrence on June 20-22; subject of the meetings was "Non Western Materials for the Undergraduate Collection."

A Preconference meeting of the Junior College Libraries Section of ACRL was cosponsored by JCLS, and the American Association of Junior Colleges. Subject of the meetings was "Library Services to Vocational-Technical Education Programs in Junior Colleges.

Lawrence S. Thompson presided at the Preconference meeting of the Rare Books Section of ACRL on June 20-22 at Dixon Inn in Kansas City, Mo. Approximately one hundred fifty librarians and booksellers were present. At the opening session of the institute on "The Antiquarian Book Trade in the Twentieth Century" a panel of speakers considered whether the sources of antiquarian books were drying up; the role of the private collector; the relationship of the antiquarian bookseller and the librarian; and the function of the international bookdealer. While some felt that it took sorcery to turn up new sources, one speaker observed that this view was perpetuated by lazy booksellers, uninformed librarians, and silly book collectors. He felt that the supply of books would continue as long as we remember that today's commonplaces are tomorrow's rarities, and cease to yearn for the unprocurable. Cooperation, especially in the understanding of problems faced by the dealer and the librarian, was called for.

In the following sessions the past, present, and future of the trade in Great Britain, France, the Germanies, Italy, Spain, Scandinavia, Holland, South and Central America, and the United States were considered. Many useful histories and bibliographies were cited, and the following points made, amongst others.

The private collector was seen as a declining source and customer in England, a constant in France, and an increasingly important factor in Italy. In England the catalog stood at the top of the list of means of selling books, and shop visits at the bottom. The individualistic nature of the
French, and government regulations, were seen as accounting for the importance of buying directly from shops in France, and for the booksellers' preference for cash transactions. Government regulations presented problems in most of the countries discussed. In Germany under the Nazis stocks were destroyed, and this destruction deepened during World War II. Total stocks stood at three to four million after the war, although three firms alone could have made up that total in 1933. The flight of dealers under the Nazis at least enriched the rest of the world, although at a tragic price.

In Italy the proportion of small amateur dealers is high and considerable reliance is placed on a network of scouts. The great private libraries of the south should prove a fruitful source of stock, but one difficult to tap. Spain and Spanish America both present pictures of somewhat haphazard collecting and problems in meeting export regulations. Although the bulk of the trade of the antiquarian dealers in the Scandinavian countries and Holland is in books in the language of their own countries, we must turn to them increasingly for the completion of great scholarly collections in general subjects, and, of course, in their own histories and cultures. Finally, the United States presents us with the greatest number of antiquarian booksellers with the greatest diversity in their specialties.

The talks were summarized at the meeting of the Mississippi Valley Regional Group of the Bibliographical Society of America, where the value of meetings at which the dealer, the collector, and the librarian could talk together was reemphasized. That summary will be published in $A B$ : Bookman's Weekly and the papers themselves will appear in The $1969 \mathrm{AB}$ Bookman's Yearbook.-Howell J. Heaney.

\section{CONFERENCE PROGRAMS}

The Kansas City Conference program meeting of ACRL was held on June 24. Dan M. Lacy, McGraw-Hill Book Company, spoke on the report of the National Advisory Commission on Libraries and its implications for academic and research libraries. Anne Edmonds spoke on the implications of the report for accrediting agencies and Norman Tanis on its impli- 
cations for Standards. Warren J. Haas discussed the implications of the report for surveys.

\section{College Libraries Section}

Audrey North, chairman, presided at the business and program meeting of the College Libraries Section of ACRL on June 25. Approximately two hundred were present. After a very brief business meeting, the program portion of the meeting was opened by a short talk on Interinstitutional Systems and the College Library: a Forward Look by Audrey North, who Iater introduced Frederick G. Kilgour, E. J. Josey, and Robert W. Evans, who presented a summary and remarks. Mr. Kilgour, director of the Ohio College Library Center, Ohio State University spoke on "Contributions of Regional Computerization to Small Colleges" addressing himself specifically to the problems of the independent small colleges. $\mathrm{He}$ emphasized the role which the library should take in the total educational program, urging that the library both stimulate the improvement of teaching methods and support those changes which are initiated by administration and faculty, not lag behind nor obstruct. Mr. Josey, associate in academic and research libraries in the division of library development of the New York State library, Albany, had as his topic "The Role of the College Library in the 3R's System." Mr. Josey opened his address by explaining that " $3 R$ 's" is the nickname for the Reference and Research Library Resources program which developed to meet the great needs of advanced researchers and scholars in New York, whether or not they were connected with institutions of higher education. New York had rich resources, but only a small proportion of those who needed material had access to it. To improve this situation nine regional systems were set up with state support which in the year April 1, 1968-March 31, 1969, amounts to $\$ 1,250,000$. Mr. Josey reported the organization of the regional systems and the results of a questionnaire sent to a sample forty college librarians regarding the operation of the plan.

Mr. Evans, associate librarian, Oberlin College, closed the program with general comments upon the topic of the section program and a few observations about cooperation in which Oberlin takes part.Iean P. Black.

\section{Subject Specialists Section}

Richard L. Snyder presided at the program and business meeting of the Subject Specialists Section of ACRL on June 25, during the Kansas City Conference. Approximately seventy-five were present. The meeting was cosponsored by the Slavic and East European Subsection and the Law and Political Science Subsection. The speakers were: Ray R. Suput, acting director, Freiberger library, Case Western Reserve University libraries, who spoke on "Advances in Soviet Librarianship and Legal Bibliography-Continuity and Change in Russian Librarianship"; and Vaclav Mostecky, assistant librarian for foreign law reference, Harvard law school library, who spoke on "Bibliographic Sources in Soviet Law."

On June 27 the Section cosponsored with the Music Library Association and the Theater Library Association, a program at the Linda Hall library, Kansas City. A panel discussed "The Role of the Subject Specialist in Librarianship."-Lois Fern.

\section{Agriculture and Biological Sciences SubSECTION}

Mrs. Pauline W. Jennings presided at the business and program meeting of the Agriculture and Biological Sciences Subsection of the ACRL Subject Specialists Section on June 24 during the Kansas City Conference. Approximately eighty-five were present. Joseph Becker, director of information science, Interuniversity Communications Council (EDUCOM), Rockville, Md., spoke on "Communications Technology and Agricultural Information," which will be published as an article in the January 1969 issue of Library Trends.-Blanche L. Oliveri.

\section{Art Subsection}

James K. Dickson presided at the Kansas City Conference meetings of the Art Subsection of ACRL's Subject Specialists Section on June 24 and June 25. Twentysix were present at the meeting on June 24, and heard Andrew W. Morgan of the Kansas City Art Institute discuss "The Cultural Circulation System in the Heart of America." At the Nelson Gallery of Art on June 25, sixty-five persons heard Laurence C. Sickman speak on "Far Eastern Books on Art-Ancient and Modern," and toured the gallery.-Nancy L. Johanson. 


\section{Education and Behavional Sciences Subsection}

Mrs. Barbara Marks presided at the organizational and program meeting of the Education and Behavioral Sciences Subsection of the ACRL Subject Specialist Section in Kansas City on June 25. Approximately fifty were present. Mrs. Marks opened the meeting and after a brief business report, turned the meeting over to the program chairman, Howard Dillon, Harvard University, Cambridge). Mr. Dillon said that a common interest of education librarians is the deficiencies in the indexing and other bibliographical control of the literature of education and therefore three speakers had been invited to form a panel on this subject: Professor Sidney Forman, Teachers College, Columbia University; George Heise, H. W. Wilson Co.; and Harvey Marron, Educational Resources Information Center, U.S. Office of Education.

Dr. Forman spoke of the increasing concern with education, in its broadest sense, by a wide variety of agencies and individuals. Bibliographical control needs to be evaluated against this background of diverse needs. The pressure is even greater in the education area because of the concern with all media. Access to the records of other countries is increasingly needed, a matter of some two thousand journals from some eighty countries. An individual, or even a scholarly association, will find the task of covering this vast area too great or the support to bolster the necessary distribution apparatus lacking. Can a commercial organization do the job? Tauber and Lilly a few years ago thought that only a government agency could do the job. Dr. Forman concluded his remarks by sketching an ideal system of bibliographical control for education and the behavioral sciences: cover all behavioral and social sciences, nationally and internationally, including what librarians have called "ephemera"; cover all media; be up-to-date; index in depth and include abstracts and translations; be compatible with emerging automated systems.

Mr. Heise sketched the history of Wilson indexes and in particular of the Education Index whose first issue was March 1929. Until the fifties periodicals to be included were selected solely by means of voting by users, but the tendency was noted to vote for only those periodicals presently subscribed to, and so an ALA committee entered the picture. In the fall of 1959 a study of Education Index began. A questionnaire went to users in May 1960, asking what should be added, what dropped, whether serials and proceedings should be included, what priorities should be adopted. Book reviews and author entries were voted to be dropped, for example, in order to extend the number of periodicals to be covered. One hundred ninety-five publications are indexed now by an editor and two indexers. Mr. Heise concluded by announcing that he hoped to see a new study of Edudation Index begin this fall.

Harvey Marron spoke of his agency (ERIC) which unlike other national information systems, is decentralized. All the ERIC product is from the local specialized clearinghouses. Not only does ERIC index and abstract, but it makes the texts available. Items to be generated are determined by the clearinghouses, and they also maintain collections of the report literature in their special fields. There are plans for an on-line retrieval system but that will be several years from now. Emphasis is on getting the quality report literature under bibliographical control and disseminated. ERIC expects to level out to about twelve thousand items per year. There are now forty-five hundred subscriptions to Research in Education, the ERIC indexing-abstracting journal, which makes it the leading federal government journal of its kind. A year ago it was thought desirable to go into periodical literature. A contract was let out to Herner and Co. of Washington to study what journals are of use to the educational community, what coverage already exists and what the Office of Education should do. The contractor has so far identified 375 titles with fifteen- to twenty-five thousand indexable items per year. Mr. Marron detailed the many problems; coverage, depth of indexing, who to index, abstract or miniabstract or plain index, overlapping, retrospective or current only, etc. The hope is that the Office of Education can go to commercial publishers to produce the publication, both to make use of their knowhow and so that they can pick up part of the cost. A proposal along these lines will be issued this summer. A question period followed. 


\section{AVAILABLE OCTOBER 1968 A MAJOR PUBLISHING EVENT:}

The 238-volume

\section{International Catalogue of Scientific Literature,}

in a 32-VOLUME REPRINT EDITION, AT A

GREATLY REDUCED PRICE -

\section{$\$ 1,500.00$}

"While issued, this was the most important current bibliography covering all the sciences."-C. M. Winchell, A Guide to Reference Books

INTERNATIONAL CATALOGUE OF SCIENTIFIC LITERATURE Sections A-R (All publ.) 1901-1914. 238 volumes.

Cloth bound in 32 volumes. . . .\$1,500.00

Section A-MATHEMATICS

Cloth bound in one volume

SEcrion B-MECHANICS

Cloth bound in one volume.

SECTION C-PHYSICS

Cloth bound in two volumes.

SECTION D-CHEMISTRY

Cloth bound in four volumes. . . . . 200.00

SECTION E-ASTRONOMY

Cloth bound in one volume..... $\quad 50.00$

Section F-METEOROLGY

Cloth bound in one volume...... 50.00

SECTION G-MINERALOGY

Cloth bound in one volume

SECTiON H-GEOLOGY

Cloth bound in one volume.

SECTION J-GEOGRAPHY

Cloth bound in one volume.
$\$ 45.00$

27.50

85.00

50.00

55.00

60.00
SEction K-PALEONTOLOGY

Cloth bound in one volume...... \$45.00

SECTION L-GENERAL BIOLOGY

Cloth bound in one volume...... 27.50

SECTION M-BOTANY

Cloth bound in three volumes..... 180.00

SECTION N-ZOOLOGY

Cloth bound in five volumes...... 290.00

Section O-HUMAN ANATOMY

Cloth bound in one volume..... 50.00

SECTION P-ANTHROPOLOGY

Cloth bound in two volumes...... 85.00

SECTION Q-PHYSIOLOGY

Cloth bound set in four volumes... 240.00

SECTION R-BACTERIOLOGY

Cloth bound in two volumes.

Johnson Reprint is able to offer the International Catalogue of Scientific Literature at a greatly reduced price because we reprint four pages of the original Catalogue to every one of the large $\mathrm{J} / \mathrm{R}$ edition $\left(9^{\prime \prime} \times 121^{\prime \prime}\right)$. Write for our detailed brochure showing a sample page from the reprint edition. Kindly address orders and inquiries to:

\section{Johnson Reprint Corporation,}

111 Fifth Avenue, New York, N.Y. 10003

Johnson Reprint Company, Ltd., Berkeley Sq. House, London W. 1, England 
One questioner asked $\mathrm{Mr}$. Dillon why only education, not the behavioral sciences, was featured in the program. Mr. Dillon replied that the program next year would probably emphasize the behavioral sciences, that the impetus for forming the group had come from education librarians but that the intention was to broaden the membership and the field of interest.-Wayne Gossage.

\section{University LibraRies Section}

At the program meeting of the University Libraries Section of ACRL on June 25 in Kansas City, three panel members discussed the subject of university library Standards. Stuart Forth (University of Kentucky), chairman of the Section, opened the meeting by citing the need for study and the establishment of Standards for university libraries. Norman Tanis, Kansas State College at Pittsburg, chairman of the ACRL Committee on Standards, was the first speaker, and briefly outlined the work of ACRL, ARL, and representatives from the Department of Health, Education, and Welfare Office of Education at a meeting last autumn in Boston. Mr. Tanis indicated that universities, especially new universities, need Standards for justifying budget requests. University Standards also are needed to justify federal legislation to assist such libraries, to provide statistically oriented criteria for the counseling and consulting done by the Office of Education, and for the equitable division of federal funds among all types of academic libraries. Such functions, he stated, require quantitative criteria. He pointed out that university library Standards are going to be formulated, and are indeed being formulated, although frequently by agencies not knowledgeable about university libraries. Librarians therefore should actively participate in developing Standards and assist in testing their implementation.

Robert B. Downs, dean of library administration, University of Illinois at Urbana, and chairman of the recently established ARL/ACRL committee to study university library Standards, mentioned that an initial handicap to the formulation of Standards is that many different kinds of institutions call themselves universities; that Standards for such widely diverse institutions would be meaningless, difficult to gain acceptance for, and possibly would do more harm than good. Dr. Downs proposed two alternatives for the preparation of university library Standards- (1) formulation of ideal Standards-which he stated would be too intangible, subjective, and controversial; (2) formulation of pragmatic Standards, based on what is regarded as the best of current practices. He favored the latter approach and suggested that the forty-two members of the Association of American Universities, or the seventy institutional members of ARL could provide the base for such a study. Frequent revision of any Standards are necessary; Dr. Downs said that every five years seems not too often.

Of his assigned subject, Standards for Collections, Dr. Downs itemized fifteen areas for which Standards might be established using a key group of university libraries for establishing criteria. Statistics for the collections of academic members of ARL might provide medians which might well become the basis for some Standards for collections. Definitions could be agreed upon after a survey, or might be the definitions adopted by the USOE, or UNESCO. Methods of counting might represent a concensus of practices followed by a control group.

Dr. Downs pointed out that although the Clapp-Jordan formula for quantitative criteria has been criticized, it nevertheless brings such criteria down to specifics. Plans proposed for the ACRL/ARL Joint Committee study differ from the Clapp-Jordan study in that the joint committee will base its work on actual university library conditions rather than on theoretical Standards. Verner Clapp and others have objected to calling norms "Standards," he said, but medians produced by the study might be called "criteria for excellence," or "significant characteristics of university libraries." Whatever they are called, however, they should not be regarded as true Standards until tested objectively by research programs to demonstrate their validity. Necessarily, such research is long range in nature, but by using the proposed procedures a tool of great utility could be developed.

On the subject of centralization versus decentralization, Dr. Downs said that its various aspects invite attempts at Standards. No area in library administration is more in need of them. 
He pointed out that after the joint committee comes up with Standards for university libraries, official standing for them will have to be obtained through endorsement by ACRL and ALA, by ARL, and by any other national library organization affected or concerned; he suggested, also, that approval and support by such groups as the Association of American Universities, American Council on Education, and Regional Accrediting Associations be requested. No matter how perfect the Standards appear when finally developed and adopted, it is certain that some people will be unhappy with them.

Gustave Harrer (University of Florida), standing in for Ellsworth Mason (Hofstra University), spoke on physical facilities. One of the things the committee is discovering, he said, is that although there is a general agreement on the part of members that Standards are feasible and necessary, most other opinions vary. For the purposes of establishing Standards, he said, there are two problems. Librarians make judgments about library service in real situations; but, the purpose of formulating Standards, factors used in subjective judgments must be analyzed and defined so that they are measurable, and differences among levels, grades, and forms must be reduced to comparable terms of measurement. The Standards must determine at which point on the scale library service becomes unacceptable.

Concerning space requirements, Standards should apply for staff, collections, or readers, taking into account ratios of undergraduates, graduates, and faculty, with concern for the commuters vs. resident students. Space for readers therefore must be considered in the light of the type of institution-urban, rural, residential. Space for collections, for example, might be extended to anticipate growth, but should be applied only to the collection. Mr. Harrer mentioned Lucien White's study of university library systems with more than one million volumes, and suggested that for the purpose of formulating Standards these libraries should be evaluated in terms of sufficiency, perhaps by categories. Mr. Harrer indicated that any statement of Standards, until more detailed information is gathered, would be premature. For the present, the collection of substantive data is required; these should then be evaluated and tested for their validity as workable university library Standards.

\title{
CUSHING-MALLOY, INC.
}

1350 North Main Street P.O. Box 632

Ann Arbor, Michigan 48107

\section{LITHOPRINTER S}

Known for

\section{QUALITY - ECONOMY - SERVICE}

\author{
Let us quote on your next printing
}




\section{Books-Coming-into-Print}

A computer-operated advance notification and acquisition program from Bro-Dart's Stacey's division. Allows your library to profile its needs in specific disciplines. Gives you notification, approval or automatic shipment of books and continuations.

\section{New and Current Books:}

An Expansion of the Books - for - Publication-Date Shelving Program.

Provides new popular fiction and non-fiction by publication date. Also makes available a continually updated index of books featured during the five previous months for libraries wishing to wait for revisions or to promptly acquire new books they may have missed.

\section{Selection Tools}

Complete computerized lists of books featured in most authoritative major collections.

\section{Cataloging and Processing}

Bro-Dart's Alanar Book Processing Center has cataloged and processed more than 12 million books for over 10 thousand libraries. The service is available on either a temporary or long term basis.

\section{Cards with Books}

Eliminates delay in securing Library of Congress catalog cards and the high cost of subsequent matching with books.

\section{Book Catalog}

Bro-Dart's extensive, existing computer programming saves libraries the heavy investment of preparing their own individual programs. Unique, practical updating system.

\section{Circulation Control Systems}

Economical solutions for all circulation control problems from simple hand-charging to systems requiring computer input.

\section{Reclassification}

Bro-Dart will propose methods, supervise, and even provide the necessary manpower to accomplish reclassification with minimum disruption of services.

\section{Library Furniture}

Bro-Dart manufactures and supplies complete ranges of library furniture in styles to complement any budget and decor.

\section{Library Supplies}

Every kind of supply imaginable for efficient library management to help a librarian acquire, catalog, process, shelve, circulate, and repair books and periodicals.

56 Earl Street, Newark, New Jersey 07114 Newark • Williamsport • Los Angeles • Brantford, Ontario

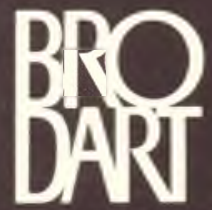

For more information write Dept. CRL-9a. 


\section{Harvard University Library \\ CATALOGUE OF HEBREW BOOKS}

The 75,800 cards in the Hebrew catalogue of the Harvard University Library are here photographically reproduced, 21 cards to a page at a $50 \%$ reduction, in six sturdily bound $9 \times 12$ inch volumes. The first four volumes comprise a dictionary catalogue of authors and subjects; the last two are a catalogue of Hebrew titles. The collection is especially rich in rabbinic literature. The library has an excellent collection of belles-lettres, philology, and materials dealing with Jewish history and culture in the Diaspora and in Israel, and it includes much on East European Jewry and on Zionism. The collection on Israel in general and on its Jewish community in particular is also noteworthy. The Catalogue's usefulness is enhanced by the inclusion of a considerable number of Library of Congress depository cards for books not in Harvard's collection. A prospectus describing the Catalogue in further detail is available on request. 3,611 pp. 6 vols. $\$ 225.00$ the set.

\section{Harvard University Library}

\section{CATALOGUE OF ARABIC, PERSIAN, AND OTTOMAN TURKISH BOOKS}

Similar in format to the Catalogue of Hebrew Books, this five-volume work reproduces the 67,000 cards in the catalogue of the library's Middle Eastern collections. The first three volumes provide an author, title, and personal-subject catalogue of the Arabic books; volume four contains similar dictionary catalogues of the Persian and the Ottoman Turkish books; and volume five provides a topical subject index in one alphabet of all books listed in the other volumes. The prefatory matter in volume one summarizes the history of Middle Eastern studies and resources in the United States. The University's catalogued Middle Eastern collections contain approximately 31,000 volumes in Arabic, 6,000 in Persian, and 4,000 in Ottoman Turkish. Both classical and modern works are well represented. Ninteenth- and twentieth-century periodicals are an outstanding feature. The Catalogue includes a considerable number of Library of Congress depository cards for Arabic and Persian books not in Harvard's collection. A prospectus is available on request. $3,200 \mathrm{pp}$. 5 vols. $\$ 195.00$ the set.

Distributed for the Harvard University Library.

All orders and requests for further information should be sent to

\section{HARVARD UNIVERSITY PRESS}

79 Garden Street, Cambridge, Massachusetts 02138 